Tropical Journal of Pharmaceutical Research February 2021; 20 (2): 403-409

ISSN: $1596-5996$ (print); 1596-9827 (electronic) (C) Pharmacotherapy Group, Faculty of Pharmacy, University of Benin, Benin City, 300001 Nigeria

\title{
Effect of angiotensin converting enzyme gene polymorphism on patients with in-stent restenosis after percutaneous coronary intervention
}

\author{
Tarek A Abdelaziz ${ }^{1 *}$, Randa H Mohamed ${ }^{2}$, Gehan F Balata ${ }^{3}$, Omar Y El-Azzazy ${ }^{4}$ \\ ${ }^{1}$ Department of Cardiology, ${ }^{2}$ Department of Medical Biochemistry, Faculty of Medicine, ${ }^{3}$ Department of Pharmaceutics, \\ ${ }^{4}$ Department of Pharmacy Practice, Faculty of Pharmacy, Zagazig University, Zagazig, Egypt
}

*For correspondence: Email: oyhaz631@gmail.com; Tel: +20-1092392870

Sent for review: 30 August 2020

Revised accepted: 22 January 2021

\begin{abstract}
Purpose: To evaluate the association between common single nucleotide polymorphisms (SNPs) in angiotensin converting enzyme (ACE) gene and the risk of in-stent restenosis (ISR) and/or the response to angiotensin converting enzyme inhibitor ACEI in individuals with stable coronary artery disease (CAD) after stent implantation.

Methods: The total population of this study consisted of 200 Egyptian individuals divided into 2 groups in-stent restenosis (ISR) and non ISR group). Genomic DNA was withdrawn from EDTA whole blood applying a spin column approach and ACE gene insertion/deletion (I/D) polymorphisms were determined by polymerase chain reaction (PCR).

Results: Carriers of allele D of ACE gene were significantly more liable to ISR occurrence. However, carriers of allele I were significantly more liable to ISR occurrence after administration of ACEI. There is a negative interaction between DD genotype of ACE gene and ACEI administration on ISR after percutaneous coronary intervention (PCI). However, there is a positive interaction between II and ID genotype of ACE gene and ACEI administration on ISR after PCI with bare metal stents (BMS).

Conclusion: It is beneficial to implement ACEI in therapeutic regimen in individuals with ID or II genotypes of ACE gene, especially with BMS implementation.
\end{abstract}

Keywords: ACE gene, In-stent restenosis, Polymorphism, Coronary artery disease

This is an Open Access article that uses a fund-ing model which does not charge readers or their institutions for access and distributed under the terms of the Creative Commons Attribution License (http://creativecommons.org/licenses/by/4.0) and the Budapest Open Access Initiative (http://www.budapestopenaccessinitiative.org/read), which permit unrestricted use, distribution, and reproduction in any medium, provided the original work is properly credited.

Tropical Journal of Pharmaceutical Research is indexed by Science Citation Index (SciSearch), Scopus, International Pharmaceutical Abstract, Chemical Abstracts, Embase, Index Copernicus, EBSCO, African Index Medicus, JournalSeek, Journal Citation Reports/Science Edition, Directory of Open Access Journals (DOAJ), African Journal Online, Bioline International, Open-J-Gate and Pharmacy Abstracts

\section{INTRODUCTION}

There is a serious complication after stable coronary artery disease (CAD) or acute coronary syndrome known as In-stent restenosis (ISR). This stent generation overcomes the preceding disadvantages including ISR[1]. Genes such as ACE gene or eNOS gene may perform a crucial province in improvement of ISR between CAD patients. Endothelin-1, TGF- $\beta$, angiotensin II and nitric oxide (NO) are set free from injured endothelial cells participating in the hyperplasia of endomembrane and cell proliferation of smooth muscle leading to subsequent rise in ISR [2].

Several studies investigated the consequences of polymorphisms in ISR in genes especially 
encoding various receptors, enzymes, and growth factors. Although several reports have not indicated the implied purposes of functional polymorphisms in several genes as vascular endothelial growth factor, endothelial nitric oxide synthase and transforming growth factor- $\beta$, these studies indicated an association between ISR and single nucleotide polymorphisms (SNPs) in these genes [3,4].

An important clinical obstacle that should be considered is the alteration of individuals response to drugs which may rely on different factors like body weight, gender, genetics, age, organ function, drug interactions, disease states, culture, lifestyle, smoking and diet [5]. Moreover, genetic alteration is the most sensitive factor affecting the alteration of individuals response to drugs [5]. If ISR can be related to SNPs, it may be obvious why the repetition of stent implantation is still required and also why genetic screening is needed for these patients.

The aim of this research was to estimate the correlation between SNPS in the ACE gene polymorphism and the liability of ISR occurrence in Egyptian individuals following stent implantation with stable coronary artery disease. Additionally, the correlation between ACE gene polymorphism and the response to patients' medications (ACEls) was evaluated.

\section{METHODS}

\section{Patient samples collection}

Study subjects include 200 Egyptian patients which separated into 2 groups. The patients of the first group (100 case) had complications of in-stent restenosis while those of the second group (100 case) that did not show complications of in-stent restenosis after $\mathrm{PCl}$. The patients were enrolled from Cardiology Section of hospitals of Zagazig University from March 2018 to December 2019. This research was approved by the institutional review board (IRB) in Zagazig University (medical ethics committee of Zagazig University) (IRB no. 5097). All patients were treated following the principles in the declaration of Helsinki [6]. Coronary angiography confirmed in-stent stenosis which was outlined as renarrowing of vessel lumen to $>50 \%$ in 3 to 12 months after $\mathrm{PCl}$. According to the European Society of Cardiology, when systolic blood pressure is more than or equal $139 \mathrm{~mm} \mathrm{Hg}$ and/or diastolic blood pressure is more than or equal $89 \mathrm{~mm} \mathrm{Hg}$ in two different measurements or when the patient is on hypertension medication, the patient is indicated as a hypertensive case. Additionally, individuals are referred to be smokers when they have 5 cigarettes/day or more and non-smokers when they had never smoked or had discontinued smoking for at least one-year preceding sample collection. Moreover, obesity was determined for women as waist-to-hip ratio of more than 0.85 and for men as waist-to-hip ratio of more than 0.9 .

\section{Isolation of DNA}

Genomic DNA was withdrawn from EDTA whole blood (whole human peripheral blood which is collected in sterile vacutainer tubes containing the anticoagulant Ethylene diamine tetra acetic acid (EDTA)) applying a spin column approach in agreement with the protocol (QIAamp Blood Kit; Qiagen $\mathrm{GmbH}$, Hilden, Germany).

\section{Genetic polymorphism detection}

PCR identified the ACE gene insertion/deletion (I/D) polymorphisms genotyping by forward 5'CTGGAGACCACTCCCATCCTTTCT-3' primer and reverse 5'-ATGTGGCCATCACATTCGTCA GAT-3' primer. There was no bias about any group when genotyping was performed and evaluated. The PCR product of ACE gene was either 490 bp (I allele) or 190bp (D allele). On 3\% agarose gel dyed with ethidium bromide, the PCR products were separated and subsequently the gel was examined with ultraviolet transilluminator using one hundred bp ladder.

\section{Statistical analysis}

Descriptive data were demonstrated as mean \pm standard deviation. Statistical differences were analyzed applying Student's t-test or one-way analysis of variance (ANOVA) then Fisher's least significant difference (LSD) and/or post hoc test (in case of 2 sets of data or more were being correlated). Hardy-Weinberg equilibrium was used to evaluate genotype frequencies and any difference from the anticipated frequencies was evaluated for significance. Moreover, 95\% confidence intervals (Cls) and the odds ratios (ORs) concerning the existence of genotype allele and polymorphism with respect to the presence of ISR and/or specific drug administration were estimated. To analyze possible synergism between ACE gene polymorphism, ACEI and ISR, a $4 \times 2$ table outline was applied to estimate ORs, $95 \% \mathrm{Cls}, p$ values and synergy index (SI). It was presumed that the protected person without the vulnerable genotype carried a specific liability for disease (OR00 is presumed to be 1). Also, OR10 indicates the corresponding liability for disease between individuals without the vulnerable 
genotype for disease but prone to the environmental risk factor compared to those with not either the liability genotype or exposure. In addition, OR01 indicates the corresponding liability between individuals with the vulnerable genotype who are protected from the risk factor compared to those with no vulnerable genotype and exposure. Moreover, OR11 indicates the proportion of disease liability between unprotected people with vulnerable genotype to disease liability between protected individuals without the vulnerable genotype. Consequently, these ORs were applied to estimate the SI which is $\mathrm{SI}=(\mathrm{OR} 11-1) /(\mathrm{OR} 10+\mathrm{OR} 01-2)[7]$. Differences were regarded significant at $p$ less than 0.05 . SPSS version 10 for windows was used to calculate the whole data.

\section{RESULTS}

In this study, 200 cases were separated into 2 groups. Patients in the first group (100 cases) (ISR) had complications of in-stent restenosis and those of the second group (100 cases) (NonISR) did not show complications of in-stent restenosis after $\mathrm{PCl}$ with $\mathrm{DES}$.

\section{Characteristics of study patients}

ISR group had significant increase in male frequency while Non-ISR group had significant increase in female frequency. Moreover, there was significant increase in hypertension, diabetes, CKD, obesity and length of stent in ISR group in comparison with Non ISR group.

\section{Monitoring of ACE gene polymorphism (II, DD and ID) and their allele frequency}

The frequencies of genotype ID of ACE gene were significantly higher in ISR patients than non-ISR group (genotype ID was $46 \%$ versus 36 $\%)$. Carriers of genotype ID were significantly more expected to develop ISR than carriers of genotype II [OR $=5.8, \mathrm{Cl}=(1.17-28.3), p<0.05]$. Based on the allelic frequencies of the ACE gene polymorphism of ISR and non-ISR group, it was observed that the allele $D$ genotype frequencies were significantly more in ISR group than NonISR group (75 \% versus $27 \%)(p<0.0001)$. Therefore, carriers of allele $D$ were significantly more expected to develop ISR than carriers of I allele $(\mathrm{OR}=8.1, \mathrm{Cl}=(5.2-12.7), \mathrm{p}<0.0001)$.

Table 1: Characteristics of study patients

\begin{tabular}{|c|c|c|c|c|}
\hline Variable & & $\begin{array}{c}\text { ISR } \\
(n=100)\end{array}$ & $\begin{array}{c}\text { Non ISR } \\
(n=100)\end{array}$ & $p$ value \\
\hline \multicolumn{5}{|l|}{ Gender } \\
\hline$>$ & Male & 84 & 60 & $<0.001$ \\
\hline$>$ & Female & 16 & 40 & $<0.001$ \\
\hline Age & & $57 \pm 0.25$ & $58.10 \pm 0.36$ & Ns \\
\hline Smoking & & 40 & 40 & NS \\
\hline Hypertension & & 80 & 35 & $<0.0001$ \\
\hline Familial history & & 8 & 4 & NS \\
\hline Diabetes mellitus & & 66 & 40 & $<0.001$ \\
\hline Dyslipidemia & & 32 & 28 & NS \\
\hline Chronic kidney disease & & 6 & 0 & $<0.05$ \\
\hline Obesity & & 44 & 24 & $<0.01$ \\
\hline Myocardial infarction & & 12 & 6 & NS \\
\hline \multicolumn{5}{|l|}{ Type of stent } \\
\hline$>\quad$ DES & & 44 & 58 & ns \\
\hline$>\quad \mathrm{BMS}$ & & 56 & 42 & ns \\
\hline Length of stent & & $26.5 \pm 0.49$ & $20.6 \pm 0.25$ & $<0.0001$ \\
\hline Diameter of stent & & $2.9 \pm 0.0009$ & $2.95 \pm 0.0004$ & Ns \\
\hline
\end{tabular}

Table 2: Monitoring of ACE gene polymorphism (II, DD and ID) and their allele frequency between ISR group and Non ISR group after $\mathrm{PCl}$

\begin{tabular}{lcccc}
\hline $\begin{array}{l}\text { ACE gene } \\
\text { polymorphism }\end{array}$ & $\begin{array}{c}\text { ISR } \\
(\mathbf{n = 1 0 0 )}\end{array}$ & $\begin{array}{c}\text { Non ISR } \\
(\mathbf{n = 1 0 0 )}\end{array}$ & $\begin{array}{c}\text { OR } \\
(\mathbf{9 5 \%} \mathbf{C l})\end{array}$ & $\boldsymbol{p}$ value \\
\hline II & $2(2 \%)$ & $9(9 \%)$ & 1 & - \\
DD & $52(52 \%)$ & $55(55 \%)$ & $4.3(0.87-20.6)$ & $\mathrm{ns}$ \\
ID & $46(46 \%)$ & $36(36 \%)$ & $5.8(1.17-28.3)$ & $<0.05$ \\
Alleles & ISR & Non ISR & & \\
& $(\mathbf{n = 2 0 0 )}$ & $(\mathbf{n = 2 0 0 )}$ & & - \\
I allele & $50(25 \%)$ & $146(73 \%)$ & 1 & $<0.0001$ \\
D allele & $150(75 \%)$ & $54(27 \%)$ & $8.1(5.2-12.7)$ & \\
\hline
\end{tabular}


Monitoring of ACE gene polymorphism (II, DD and ID) and their allele frequencies in patients administered ACEI

As Table 3 shows the frequencies of genotype II and ID of ACE gene were significantly more in ISR group than Non-ISR group in patients administered ACEI (genotype II was $11.1 \%$ versus $1.3 \%$ and genotype ID was $51.9 \%$ versus $36.8 \%$ ). Carriers of genotype II and ID were significantly more expected to develop ISR than carriers of genotype DD [OR $=14.1, \mathrm{Cl}=$ (1.6 - 124.9), $p<0.01]$ and $(\mathrm{OR}=2.35, \mathrm{Cl}=$ $(1.12-4.9), p<0.05)$ respectively.

Based on the allelic frequencies of the ACE gene polymorphism of ISR and Non ISR group in patients administering ACEI, it was observed that the frequencies of allele I genotype were significantly more in ISR group than Non ISR (37 $\%$ versus $19.7 \%)(p<0.01)$.

Therefore, carriers of allele I were significantly more expected to develop ISR than carriers of $D$ allele $(\mathrm{OR}=2.4, \mathrm{Cl}=(1.36-4.2), p<0.01)$.

\section{Synergistic effect of ACE gene polymorphism, ACEI and ISR}

Patients who administered ACEI and had DD genotype of ACE gene have significantly decreased risk to develop ISR than those who did not administer ACEI and had DD genotype of ACE gene $(\mathrm{OR}=0.23(95 \% \mathrm{Cl}=0.1-0.53 ; p<$ 0.001 ) which subsequently proposed the protective role of ACEI (ISR group 20\% versus non-ISR $40 \% ; p<0.001)$. Synergy index (SI = 0.56 ) indicated a negative interaction between DD genotype of ACE gene and ACEI administration on ISR after PCI.

\section{Synergistic effect of ACE gene polymorphism, ACEI and ISR after $\mathrm{PCl}$ with BMS}

Patients who administered ACEI and had DD, II or ID genotype of ACE gene have significantly decreased risk to develop ISR than those who did not administer ACEl and had DD genotype of ACE gene $(\mathrm{OR}=0.31 ; 95 \% \mathrm{Cl}=0.1-0.9 ; p<$ 0.05 and $\mathrm{OR}=0.16 ; 95 \% \mathrm{Cl}=0.05-0.5 ; p<$ $0.01)$ respectively which consequently proposed the protective role of ACEI (ISR group versus non-ISR was $25 \%$ vs $35.7 \% ; p<0.05$ and 12.5 $\%$ vs $35.7 \% ; p<0.01$, respectively). Synergy index $(S I=1.1)$ indicated an additive interaction between II and ID genotypes of ACE gene and ACEI administration on ISR after PCI with BMS.

\section{Synergistic effect of ACE gene polymorphism, ACEI and ISR after PCI with DES}

Patients who administered ACEI and had DD, II or ID genotype of ACE gene had no significant difference to develop ISR than those who did not administer ACEI and had DD genotype of ACE gene. Therefore, the Synergy index was not significant and did not have any impact on ISR after PCI with DES.

Table 3: ACE gene polymorphism (II, DD and ID) and their allele frequencies between ISR group and non-ISR group after $\mathrm{PCl}$ in patients administered $\mathrm{ACEI}$

\begin{tabular}{|c|c|c|c|c|}
\hline $\begin{array}{l}\text { ACE gene polymorphism } \\
\text { Patient taking ACEI }\end{array}$ & $\begin{array}{c}\text { ISR } \\
(n=54)\end{array}$ & $\begin{array}{c}\text { non-ISR } \\
(\mathrm{n}=76)\end{array}$ & $\begin{array}{c}\text { OR } \\
(95 \% \mathrm{Cl})\end{array}$ & $p$ value \\
\hline DD & $20(37 \%)$ & $47(61.9 \%)$ & 1 & - \\
\hline II & $6(11.1 \%)$ & $1(1.3 \%)$ & $14.1(1.6-124.9)$ & $<0.01$ \\
\hline ID & $28(51.9 \%)$ & $28(36.8 \%)$ & $2.35(1.12-4.9)$ & $<0.05$ \\
\hline Alleles & $\begin{array}{c}\text { ISR } \\
(n=108)\end{array}$ & $\begin{array}{l}\text { non ISR } \\
(n=152)\end{array}$ & & \\
\hline D allele & $68(63 \%)$ & $122(80.3 \%)$ & & \\
\hline I allele & $40(37 \%)$ & $30(19.7 \%)$ & $2.4(1.36-4.2)$ & $<0.01$ \\
\hline
\end{tabular}

ACE: Angiotensin converting enzyme and ACE: Angiotensin converting enzyme inhibitor

Table 4: Synergistic effect of ACE gene polymorphism, ACEI and ISR

\begin{tabular}{|c|c|c|c|c|c|c|}
\hline ACEI & II + ID & $\begin{array}{c}\text { ISR } \\
(N=100)\end{array}$ & $\begin{array}{l}\text { non-ISR } \\
(N=100)\end{array}$ & $\begin{array}{c}\text { OR } \\
(95 \% \mathrm{Cl})\end{array}$ & $p$ value & $\begin{array}{l}\text { Synergy index } \\
\text { (SI) }\end{array}$ \\
\hline 0 & 0 & $32(32 \%)$ & $15(15 \%)$ & & & 0.56 \\
\hline 0 & 1 & $14(14 \%)$ & $9(9 \%)$ & $\begin{array}{c}0.73 \\
(0.26-2.1)\end{array}$ & ns & \\
\hline 1 & 0 & $20(20 \%)$ & $40(40 \%)$ & $\begin{array}{c}0.23 \\
(0.1-0.53)\end{array}$ & $<0.001$ & \\
\hline 1 & 1 & $34(34 \%)$ & $36(36 \%)$ & $\begin{array}{c}0.42 \\
(0.2-0.96)\end{array}$ & ns & \\
\hline
\end{tabular}


Table 5: Synergistic effect of ACE gene polymorphism, ACEI and ISR after PCI with BMS

\begin{tabular}{llccccc}
\hline ACEI & II + ID & $\begin{array}{c}\text { ISR } \\
(\mathbf{n = 5 6 )}\end{array}$ & $\begin{array}{c}\text { non ISR } \\
(\mathbf{n = 4 2 )}\end{array}$ & $\begin{array}{c}\text { OR } \\
(\mathbf{9 5 \%} \mathbf{~ C l})\end{array}$ & $\boldsymbol{p}$ value & $\begin{array}{c}\text { Synergy index } \\
\text { (SI) }\end{array}$ \\
\hline 0 & 0 & $24(42.8 \%)$ & $8(19 \%)$ & & & \\
0 & 1 & $11(19.7 \%)$ & $4(9.6 \%)$ & $0.9(0.23-3.7)$ & ns & $\mathbf{1 . 1}$ \\
1 & 0 & $14(25 \%)$ & $15(35.7 \%)$ & $0.31(0.1-0.9)$ & $<0.05$ & \\
1 & 1 & $7(12.5 \%)$ & $15(35.7 \%)$ & $0.16(0.05-0.5)$ & $<0.01$ & \\
\hline
\end{tabular}

Table 6: Synergistic effect of ACE gene polymorphism, ACEI and ISR after PCI with DES

\begin{tabular}{|c|c|c|c|c|c|c|}
\hline ACEI & DD + ID & $\begin{array}{c}\text { ISR } \\
(\mathrm{n}=44)\end{array}$ & $\begin{array}{c}\text { non-ISR } \\
(\mathrm{n}=58)\end{array}$ & $\begin{array}{c}\text { OR } \\
(95 \% \mathrm{Cl})\end{array}$ & $p$ value & $\begin{array}{l}\text { Synergy index } \\
\text { (SI) }\end{array}$ \\
\hline 0 & 0 & $0(18.2 \%)$ & $1(12 \%)$ & & & \\
\hline 0 & 1 & $11(6.8 \%)$ & $11(8.6 \%)$ & $3(0.1-81.7)$ & ns & \\
\hline 1 & 0 & $0(13.6 \%)$ & $8(43.2 \%)$ & $\begin{array}{c}0.18(0.002- \\
12.8)\end{array}$ & ns & 1.36 \\
\hline 1 & 1 & $33(61.4 \%)$ & $38(36.2 \%)$ & $2.6(0.1-66.3)$ & ns & \\
\hline
\end{tabular}

\section{DISCUSSION}

This study demonstrated a significant increase in male frequency, length of stent, hypertension, diabetes, CKD and obesity in ISR group relative to Non-ISR group suggesting that these are risk factors for ISR.

These results are consistent with previous studies which demonstrated that chronic kidney disease, diabetes and longer stents were associated with a higher rate of restenosis [8]. Moreover, previous studies supported these results and showed that hypertension and obesity are risk factors that increase inflammation markers and therefore increase stent restenosis [9].

However, Ekizler et al found that females in comparison with males were associated with a higher rate of ISR occurrence after BMS implantation [10]. On the other hand, another study indicated that female gender was not a separate indicator of ISR occurrence regardless of stent type [11].

This study indicated that the frequencies of genotype ID of ACE gene were significantly more in ISR group than non ISR group and Carriers of genotype ID were significantly expected to develop ISR than carriers of genotype II.

These results were compatible with the metaanalysis performed by Agema et al which indicated that ID genotype increased the risk for restenosis after stent implantation [12]. Additionally, Guneri et al [13] reported no association among ACE gene polymorphism and stent restenosis. It was observed that the allele D genotype frequencies were significantly more in ISR group than Non-ISR group and carriers of allele D were significantly more expected to develop ISR than carriers of I allele.

These results were in accordance with Wang et al showing that the DD genotype of ACE gene polymorphism was significantly correlated with increased liability of restenosis [14]. Meurice et al indicated that ACE D allele carriers had a higher rate of restenosis suggesting that ACE D allele is significantly correlated to restenosis [15].

These results may be explained by previous reports which showed that ACE activity of the left ventricle was greater in people with $D$ allele and transformation of angiotensin I to angiotensin II was higher in individuals with the DD genotype demonstrating greater ACE activity in the existence of $D$ allele and therefore higher risk for ISR [16]. Moreover, Tiret et al indicated that DD genotype of the ACE gene showed significantly greater angiotensin II levels and ACE activities than II or ID genotype indicating a greater liability of ISR for DD genotype carriers [17].

This study showed that the frequencies of genotype II and ID of ACE gene were significantly more in ISR group than Non-ISR group in patients administered ACEI and carriers of genotype II and ID were significantly more expected to develop ISR than carriers of genotype DD.

However, the frequencies of allele I genotype were significantly more in ISR group than Non ISR and carriers of allele I were significantly more expected to develop ISR than carriers of $D$ allele in patients administering ACEI.

These results may be explained by previous studies which showed that Genotype DD is associated with increased response to ACEI more than II and ID genotypes especially in patients with hypertension, dyslipidemia and 
smokers [19]. As ACEI had protective role on ISR patients with D allele [20] and genotype DD was associated with increased response to ACEI more than II and ID genotypes, hence I allele may play a risk factor in patients administering $A C E I$ in their therapeutic regimen.

Synergy index in the study $(\mathrm{SI}=0.56)$ indicated the protective role of $A C E I$ administration on ISR after $\mathrm{PCl}$ in subjects carrying DD genotype.

One study suggested that ACEI had protective role on ISR patients with $D$ allele (restenosis group $43.5 \%$ vs $56.5 \%$ in non-restenotic group [13]. However, previous studies indicated that ACE D allele carriers possessed a higher rate of restenosis indicating that ACE $D$ allele is significantly correlated to restenosis [15]. Lee et al also reported that $A C E I$ was associated with lower risk for ISR and subsequently lower need for revascularization. Moreover, it indicated that DD genotype of ACE gene was correlated with higher incidence for revascularization [21].

These studies may explain the negative interaction (antagonism) between DD genotype which is a risk factor for ISR and ACEI which has a protective effect on ISR patients with $D$ allele.

Synergy index (SI= 1.1) in this study between II and ID genotypes of ACE gene and ACEI administration on ISR after $\mathrm{PCl}$ with BMS indicated that there was an additive interaction between II and ID genotypes of ACE gene and ACEI administration. Several studies demonstrated that II and ID genotypes had more response and less resistance for $A C E I$ than DD genotype proposing a protective role for II and ID genotypes in patients having $\mathrm{ACEl}$ in their medical strategies than compared to DD genotype [22]. Moreover, another study demonstrated that II genotype significantly reduced restenosis incidence in patients taking ACEl suggesting a protective role on ISR [18]. Therefore, these studies may illustrate the more than additive interaction (synergism) between ACEI and (II and ID) genotypes which has a protective role on ISR.

On the other hand, one study indicated that ACE inhibitor treatment exaggerated restenotic process with DD genotype when compared with administration of placebo [15].

This study showed that ACE administration did not have any impact on ISR after PCI with DES. These results were in agreement with Blendea et al that indicated there is no correlation between the incidence of restenosis and treatment with ACE inhibitors [23].

\section{Limitations of the study}

Although this study provided significant insight on the risk factors for ISR and its correlation to ACE gene polymorphism, extending the study to other races other than Egyptian patients may provide a better analysis and improved generalized conclusion.

\section{CONCLUSION}

It is better to implement $\mathrm{ACEl}$ in therapeutic regimen in individuals having II or ID genotypes of ACE gene especially with BMS implementation. For better clinical consequences, another alternative for ACEI is needed especially in patients with DD genotypes of ACE gene either DES or BMS. Furthermore, detecting allele gene polymorphisms in large sample size studies is very crucial to decreasing the harmful adverse effects of stent restenosis.

\section{DECLARATIONS}

\section{Conflict of interest}

No conflict of interest is associated with this work.

\section{Contribution of authors}

We hereby declare that this work was accomplished by the authors in this article and every responsibility referring to allegation concerning this paper will be affirmed by the authors. Prof. Dr Tarek, Randa and Gehan created and designed the study. Dr Omar collected and analyzed the results and wrote the manuscript with the assistance and revision of all the former authors. Moreover, manuscript for publication was read and accepted by all authors.

\section{Open Access}

This is an Open Access article that uses a funding model which does not charge readers or their institutions for access and distributed under the terms of the Creative Commons Attribution License (http://creativecommons.org/licenses/by/ 4.0) and the Budapest Open Access Initiative (http://www.budapestopenaccessinitiative.org/rea d), which permit unrestricted use, distribution, and reproduction in any medium, provided the original work is properly credited. 


\section{REFERENCES}

1. Kim M, Dean L. In-stent restenosis. Cardiovasc Ther 2011; 29: 190-198.

2. Pallero $M$, Talbert $R$, Chen $Y$, Anderson $P$, Lemons $J$, Brott $B$, Murphy-Ullrich J. Stainless steel ions stimulate increased thrombospondin-1-dependent TGF-beta activation by vascular smooth muscle cells: implications for in-stent restenosis. J Vasc Res 2010; 47: 309-322.

3. Gomma A, Elrayess $M$, Knight $C$, Hawe $E$, Fox $K$, Humphries S. The endothelial nitric oxide synthase (Glu298Asp and-786T> C) gene polymorphisms are associated with coronary in-stent restenosis. Eur Heart $J$ 2002; 23: 1955-1962.

4. Osadnik T, Strzelczyk J, Reguła R, Bujak K, Fronczek M, Gonera M, Gawlita M, Wasilewski J, Lekston A, Kurek $A$, et al. The relationships between polymorphisms in genes encoding the growth factors TGF- $\beta 1$, PDGFB, $E G F, b F G F$ and VEGF-A and the restenosis process in patients with stable coronary artery disease treated with bare metal stent. PLoS One 2016; 11: e0150500.

5. Brockmöller J, Tzvetkov M. Pharmacogenetics: Data, concepts and tools to improve drug discovery and drug treatment. Eur J Clin Pharmaco 2008; 64: 133-157.

6. Association W M. Declaration of Helsinki. Ethical principles for medical research involving human subjects. Jahrb Für Wiss Und Ethik 2009; 14: 233-238.

7. Rothman K. Synergy and antagonism in cause-effect relationships. Am J Epidemiol 1974; 99: 385-388.

8. Attallah N. Yassine L, Fisher K, Yee J. Risk of bleeding and restenosis among chronic kidney disease patients undergoing percutaneous coronary intervention. Clin Nephrol 2005; 64: 412-418.

9. Kornowski R, Hong M, Tio F, Bramwell O, Wu H, Leon M. In-stent restenosis: contributions of inflammatory responses and arterial injury to neointimal hyperplasia. $J$ Am Coll Cardiol 1998; 31: 224-230.

10. Ekizler F. Impact of Gender on Restenosis Following Coronary Artery Stenting. Am J Cardiol 2018; 121: e70.

11. Solinas E, Nikolsky E, Lansky A, Kirtane A, Morice M, Popma J, Schofer J, Schampaert E, Pucelikova T, Aoki $J$, et al. Gender-specific outcomes after sirolimus-eluting stent implantation. J Am Coll Cardiol 2007; 50: 21112116.

12. Agema W, Jukema J, Zwinderman A, Wall E. A metaanalysis of the angiotensin-converting enzyme gene polymorphism and restenosis after percutaneous transluminal coronary revascularization: evidence for publication bias. Am Heart $J$ 2002; 144: 760-768.

13. Guneri S, Baris N, Aytekin D, Akdeniz B, Pekel N, Bozdemir V. The relationship between Angiotensin converting enzyme gene polymorphism, coronary artery disease, and stent restenosis. Int Heart $J$ 2005; 46: 889-897.
14. Wang S, Dai Y, Chen L, Dong Z, Chen Y, Li C, Zhong X, Lin W, Zhang J. Genetic polymorphism of angiotensin converting enzyme and risk of coronary restenosis after percutaneous transluminal coronary angioplasties: evidence from 33 cohort studies. PLoS One 2013; 8: e75285.

15. Meurice T, Bauters C, Hermant X, Codronb V, VanBelle $E$, Fadden E, Lablanche J, Bertrand M, Amouyel P. Effect of ACE inhibitors on angiographic restenosis after coronary stenting (PARIS): a randomised, double-blind, placebo-controlled trial. Lancet 2001; 357: 1321-1324.

16. Danser A, Schalekamp M, Bax W, Brink A, Saxena P, Riegger $G$, Schunkert $H$. Angiotensin-converting enzyme in the human heart: effect of the deletion/insertion polymorphism. Circulation 1995; 92 : 1387-1388.

17. Tiret L, Rigat B, Visvikis S, Breda C, Corvol P, Cambien $F$, Soubrier $F$. Evidence, from combined segregation and linkage analysis, that a variant of the angiotensin Iconverting enzyme (ACE) gene controls plasma ACE levels. Am J Hum Genet 1992; 51: 197-205.

18. Okamura A, Ohishi M, Rakugi $H$, Katsuya $T$, Yanagitani $Y$, Takiuchi S, Taniyama $Y$, Moriguchi $K$, Ito $H$, Higashino $Y$, et al. Pharmacogenetic analysis of the effect of angiotensin-converting enzyme inhibitor on restenosis after percutaneous transluminal coronary angioplasty. Angiology 1990; 50: 811-822.

19. Prasad A, Narayanan S, Husain S, Padder F, Waclawiw $M$, Epstein N, Quyyumi A. Insertion-deletion polymorphism of the ACE gene modulates reversibility of endothelial dysfunction with ACE inhibition. Circulation 2000; 102: 35-41.

20. Bariş N, Özerkan F, Önder M, Akdeniz B, Güneri S. Relationship between angiotensin converting enzyme gene polymorphism and number of target organ damage in essential hypertension. Arch Turkish Soc Cardiol. 2004; 32: 107-114.

21. Lee J, Wu C, Tsai C, Lin L, Lin J, Chien K, Hwang J, Lin $C$, Tseng $C$, Chiang $F$, et al. Genetic variation-optimized treatment benefit of angiotensin-converting enzyme inhibitors in patients with stable coronary artery disease: a 12-year follow-up study. Pharmacogenet Genomics 2013; 23: 181-189.

22. Mizuiri S, Hemmi H, Inoue A, Takano M, Kadomatsu S, Tanimoto H, Tanegashima M, Hayashi I, Fushimi T, Hasegawa $A$, et al. Renal hemodynamic changes induced by captopril and angiotensin-converting enzyme gene polymorphism. Nephron 1997; 75: 310-314.

23. Blendea C, Chitu M, Orzan M, Bajka B, Craciun A, Benedek I. The Study of Factors Associated with Severity of In-Stent Restenosis in Patients Treated with $\mathrm{PCl}$ for Acute Coronary Syndromes. Acta Medica Marisiensis 2016; 62: 64-67.

Trop J Pharm Res, February 2021; 20(2): 409 